\title{
SEDDEER: A SEDIMENT TRANSPORT MODEL FOR WATER QUALITY MODELING
}

\author{
Y. Xiong, V. J. Alarcon, J. L. Martin, W. H. McAnally
}

\begin{abstract}
In this study, a stand-alone sediment and contaminant model, SEDDEER (Sediment Deposition and Erosion), is presented. The model simulates one water box and underlying (multiple) sediment bed layers, and was developed for incorporation into water quality models. The processes incorporated in the model are: settling and deposition, resuspension, equilibrium adsorption/desorption, sediment-water interface diffusion, volatilization and decay, sediment bed, and consolidation. In contrast to other models, SEDDEER simulates multiple sediment classes, includes a flocculation model, and considers both cohesive and noncohesive sediments. Comparisons of SEDDEER-simulated results with analytical solutions, experimental data from other studies, and simulation results from another model, EFDC (Environmental Fluid Dynamic Code), were performed. The SEDDEER algorithm for flocculation settling was successfully verified for mass conservation of both sediment and contaminant. The test for estimating settling/deposition revealed that for shear stresses of 0.00 and $0.05 \mathrm{~Pa}$, the coefficient of determination $\left(R^{2}\right)$ ranged from 0.98 to 1.00. SEDDEER's contaminant transport algorithm was tested against reported measured data of dichlorodiphenyldichloroethylene (DDE). SEDDEER-calculated output for the water column and sediment bed fit the measured data with $R^{2}=0.94$ and $R^{2}=0.74$, respectively. Lindane $(\gamma$ hexachlorocyclohexane) field data and SEDDEER output for contaminant transport also agreed well $\left(R^{2}=0.85\right)$.
\end{abstract}

Keywords. Contaminant transport, SEDDEER, Sediment transport model, Water quality.

S ediment has been identified as one of the leading nonpoint-source pollutants in the U.S. (Chao et al., 2007). The 2004 305(b) Water Quality Report to Congress (USEPA, 2009) indicates that pathogens, mercury, nutrients, and organic enrichment were the leading causes of impairment in assessed waters. Sediment in nature is closely related to the latter three causes ( $\mathrm{Zhu}$, 2006).

Sediment has a twofold effect on water quality. Sediments can temporarily purify the water by sorption and deposition. However, water also can be contaminated by desorption, resuspension, bioturbation, diffusion, and conveyance of contaminants. Particulate organic matter deposited into the sediment bed undergoes decomposition or mineralization, referred to as diagenesis ( $\mathrm{Ji}, 2008)$. Many chemical contaminants and organic wastes in aquatic ecosystems eventually accumulate in sediments, where they may adversely affect the benthic biota, become a source of contamination in the water column, accumulate in biological tissues, and enter pelagic and human food chains (DePinto et al., 1994).

Submitted for review in February 2012 as manuscript number SW 9633; approved for publication by the Soil \& Water Division of ASABE in October 2012.

The authors are Yi Xiong, Graduate Student, Department of Civil and Environmental Engineering, Vladimir J. Alarcon, Assistant Research Professor, Geosystems Research Institute, James L. Martin, Professor and Endowed Chair, Department of Civil and Environmental Engineering, and William H. McAnally, Research Engineer, Geosystems Research Institute, Mississippi State University, Mississippi State, Mississippi. Corresponding author: Vladimir J. Alarcon, Geosystems Research Institute, Box 9627, Mississippi State University, Mississippi State, MS 39759; phone: 662-325-7704; e-mail: alarcon@gri.msstate.edu.
Historically, sediment transport modeling in water quality is based on mass balance and empirical equations. Most water quality models do not have a sediment transport module. For example, the Chesapeake Bay water quality model (Cerco and Cole, 1995) included a sediment diagenesis model, but the sediment transport processes are described, calibrated, and/or specified by laboratory and in situ experiments rather than simulated from basic physical principles. A well-established water quality model, the Water Quality Analysis Simulation Program (WASP) (Wool et al., 2002), considers multiple sediment layers, sediment settling and resuspension, as well as bed layer alterations and compaction, but it does not include flocculation algorithms.

Settling velocity is the most fundamental property governing the motion of sediment particles in water ( $\mathrm{Ji}, 2008)$. For noncohesive sediment, this is a relatively simple procedure, as the settling velocity is proportional to the particle size (Baugh and Manning, 2007). However, for cohesive sediment, the settling velocity regime can be conveniently divided into three subranges: free settling, flocculation settling, and hindered settling, depending upon the sediment concentration (Hwang and Mehta, 1989). Due to its complexity, the flocculation process is not explicitly considered in most water quality modeling strategies, although there have been previous attempts to include it (e.g., Hydroqual, 2004). Cohesive sediments are linked to one another to form flocs. The settling velocity of a floc is always less than that of a solid particle of an equal diameter, generally by several orders of magnitude (Ziegler and Nisbet, 1995). Flocs connect with each other to form higher-order aggregates, which have a significant impact on sediment transport as a result of their unique properties. 
Currently, the effect of noncohesive sediment on water quality is not modeled appropriately. For example, multiple classes of cohesive/noncohesive sediment are not simulated in some models, flocculation (an indispensable process in fine sediments settling) is not considered, and some important sediment transport parameters are still obtained by calibration over wide ranges of possible values instead of calculation from first principles.

Mechanistic water quality models are based on the conservation of mass (Chapra, 1997). Box models capture much of the basic physics of mass conservation and are also of practical value in determining some of the bulk, or overall, properties (Hearn, 2008). WASP is based on the concept of a box model (Ambrose et al., 1993). Accordingly, it is reasonable to develop an easy-to-use, stand-alone, mass-conserved sediment transport box model to serve WASP and/or other models. Hence, the sediment transport and standard water quality models can be integrated without much difficulty; the improvement of the sediment transport model in WASP can be therefore readily achieved.

The objective of this study is to develop a sediment transport model, SEDDEER (Sediment Deposition and Erosion), that includes algorithms for flocculation processes, settling velocity, and a sediment bed algorithm. The model was validated using analytical solutions, results from other validated models under the same conditions, and experimental and observed data reported in other studies. The proposed model is applicable to estuaries as well as largescale stream channels.

\section{MODEL DESCRIPTION}

SEDDEER is a newly developed stand-alone mass conservation sediment transport model. SEDDEER simulates one completely mixed water box and the underlying vertically stratified sediment layers. In addition, SEDDEER includes a simple contaminant model. Processes incorporated into the model are settling and deposition, resuspension, equilibrium adsorption/desorption, sediment-water interface diffusion, volatilization and decay, sediment bed, and consolidation.

SEDDEER formulates the mass balance equation for both the water column and the sediment bed layers. The Euler explicit integration method was employed to solve the sediment and contaminant transport equations. Choosing the simplest explicit method simplified the programming process. More complex numerical methods, such as implicit or semi-implicit schemes, could be later incorporated as options to improve the model applicability and accuracy. To avoid numerical instability, time steps smaller than 10 min were used for achieving the results shown in this article. SEDDEER users, however, can choose other time-step intervals depending on their needs. Since the Euler algorithm is widely known, the details of its implementation are not reported in this article.

\section{SEDIMENT TRANSPORT MODEL}

SEDDEER sediment simulation is based on a simplified governing equation (eq. 1) for one completely mixed box in water column per unit area (Chapra, 1997):

$$
\frac{d C_{i} H_{\text {wat }}}{d t}=\frac{Q_{\text {in }}}{A_{\text {wat }}} C_{\text {ini }}-\frac{Q_{\text {out }}}{A_{\text {wat }}} C_{i}+L_{i}+I_{i}+E_{i}-D_{i}
$$

where $C_{i}$ is the concentration of the $i$ th sediment class $(\mathrm{kg}$ $\left.\mathrm{m}^{-3}\right) ; H_{\text {wat }}$ is the depth of the water box (m); $Q_{\text {in }}$ is the inflow flow rate $\left(\mathrm{m}^{3} \mathrm{~s}^{-1}\right) ; A_{\text {wat }}$ is the horizontal area of the water box $\left(\mathrm{m}^{2}\right) ; C_{i n i}$ is the inflow concentration of the $i$ th sediment class $\left(\mathrm{kg} \mathrm{m}^{-3}\right) ; Q_{\text {out }}$ is the outflow flow rate $\left(\mathrm{m}^{3} \mathrm{~s}^{-1}\right)$; $L_{i}$ represents the external point and nonpoint source loads of the $i$ th sediment class per unit area $\left(\mathrm{kg} \mathrm{s}^{-1} \mathrm{~m}^{-2}\right) ; I_{i}$ represents the internal part, which could include reactive decay of organic sediments or mass exchange between sediment classes of floc formation and destruction $\left(\mathrm{kg} \mathrm{s}^{-1} \mathrm{~m}^{-2}, I_{i}=0\right.$ for noncohesive sediment); $E_{i}$ is the total erosion rate of the $i$ th sediment class $\left(\mathrm{kg} \mathrm{s}^{-1} \mathrm{~m}^{-2}\right)$; and $D_{i}$ is the deposition rate of the $i$ th sediment class $\left(\mathrm{kg} \mathrm{s}^{-1} \mathrm{~m}^{-2}\right)$.

Multiple sediment classes are simulated in SEDDEER, as indicated in equation 1 . The model classifies sediment based on a nominal sediment size using equation 2 , improving current sediment transport models that use a given sediment classification input. The user can specify up to ten primary sediment size bounds, which means that up to nine primary sediment classes can be simulated. For each primary cohesive and noncohesive sediment class, sediment is assumed to be spherical. If sediment size range is defined as $\left[d_{i l}, d_{i u}\right]$, then the nominal sediment size of this class is determined by (Wang and $\mathrm{Hu}, 2006$ ):

$$
d_{i}=\frac{d_{i l}+d_{i u}+\sqrt{d_{i l} \cdot d_{i u}}}{3}
$$

where $d_{i l}$ is the lower size bound of the $i$ th primary sediment class $(\mathrm{m}), d_{i u}$ is the upper size bound of the $i$ th primary sediment class (m), and $d_{i}$ is the nominal size of the $i$ th primary sediment class $(\mathrm{m})$.

Sediment settling velocity has significant influence on deposition rate $D_{i}$ (as shown in eq. 1). Based on the force balance between gravity and drag force, the free-settling terminal velocity for an individual sediment (and floc) in SEDDEER is expressed as:

$$
W_{s}=\sqrt{\frac{4}{3 C_{D}} \frac{\rho_{s}-\rho_{f}}{\rho_{f}} g d_{i}^{2}}
$$

where $W_{s}$ is the settling velocity $\left(\mathrm{m} \mathrm{s}^{-1}\right), g$ is the gravitational acceleration $\left(\mathrm{m} \mathrm{s}^{-2}\right), \rho_{s}$ is the primary sediment density $\left(\mathrm{kg} \mathrm{m}^{-3}\right) ; \rho_{f}$ is the fluid density $\left(\mathrm{kg} \mathrm{m}^{-3}\right), d_{i}$ is the sediment size (m), and $C_{D}$ is the drag coefficient for a single particle falling in the water (Camenen, 2007; Wu and Wang, 2006): $C_{D}=f\left(\operatorname{Re}_{p}\right)$, where $\operatorname{Re}_{p}$ is the particle Reynolds number. The boundary conditions for drag coefficient $C_{D}$ are as follows:

$$
C_{D}=\left\{\begin{array}{cc}
\frac{A}{\operatorname{Re}_{p}} & \operatorname{Re}_{p}<<1 \\
B & \operatorname{Re}_{p}>10^{5}
\end{array}\right.
$$


where coefficients $A$ and $B$ are as shown in table 1. Stokes' law calculates settling velocity for a special case with $\operatorname{Re}_{p}<$ 0.1 , with the drag coefficient is given by:

$$
C_{D}=\frac{24}{\operatorname{Re}_{p}}
$$

To develop a simple settling velocity formula, many researchers have tried to find a unified expression of $C_{D}$ based on the lower and upper bounds of $\mathrm{Re}_{p}$. In SEDDEER, the drag coefficient is expressed as (Camenen, 2007; Wu and Wang, 2006):

$$
C_{D}=\left[\left(\frac{A}{\operatorname{Re}_{p}}\right)^{\frac{1}{m}}+B^{\frac{1}{m}}\right]^{m}
$$

where $m$ is a coefficient. Wu and Wang (2006) calibrated $A$, $B$, and $m$ by adjusting the sediment shape factor. Taking both shape and roundness into consideration, Camenen (2007) determined $A, B$, and $m$ for typical sediments with specific shape factors and roundness based on the above Dietrich boundary equation and curves, and specific values of $A, B$, and $m$ are shown in table 1 .

In SEDDEER, the equations of Whitehouse et al. (2000) and Teeter (2001) were combined and used to calculate median flocculation-hindered settling velocity $\left(W_{s F l o c}\right)$ as a function of suspended sediment concentration $\left(C_{i}\right)$ and turbulence:

$$
W_{s F l o c}=W_{s, 50}\left[\left(\frac{1+a_{2} G}{1+a_{3} G^{2}}\right) \exp \left(-a_{4} \frac{C_{i}^{n-1}}{C_{l l}}\right)+1\right]
$$

where $W_{s, 50}$ is the settling velocity of the median-size sediment, $d_{50} ; C_{i}^{n-1}$ is the sediment concentration calculated in the previous time step; $C_{l l}$ is the lower concentration limit for flocculation settling; $a_{2}, a_{3}$, and $a_{4}$ are dimensionless empirical constants; and $G$ is average shear rate (or vertical gradient of horizontal velocity). Similarly, the equations of Whitehouse et al. (2000) and Shrestha and Orlob (1996) were combined and incorporated into SEDDEER.

SEDDEER uses the set of equations of Whitehouse et al. (2000) for the computation of flocculation-hindered settling velocity $\left(W_{s, 50}\right)$ as a function of suspended sediment concentration. First, the effective floc density $\left(\rho_{f l o c}\right)$, the volume concentration of flocs in water $\left(C_{f}\right)$, the length scale $\left(L_{f}\right)$, the effective diameter $\left(d_{e}\right)$, and the dimensionless floc diameter $\left(D_{*}\right)$ are computed, and then the median settling

Table 1. Coefficients $A, B$, and $\boldsymbol{m}$ for typical particles (after Camenen, 2007).

\begin{tabular}{cccccc}
\hline & Shape & & & & \\
Material & Factor & Roundness & $A$ & $B$ & $m$ \\
\hline Spherical particles & 1.0 & 6.0 & 24.0 & 0.39 & 1.92 \\
Smooth cobbles & 0.7 & 5.0 & 24.5 & 0.62 & 1.71 \\
Natural sand & 0.7 & 3.5 & 24.6 & 0.96 & 1.53 \\
Crushed sand & 0.7 & 2.0 & 24.7 & 1.36 & 1.36 \\
Long cylinders & 0.4 & 5.0 & 36.0 & 1.51 & 1.40 \\
Silt, cohesive particle & 0.4 & 2.0 & 38.0 & 3.55 & 1.12 \\
Flocs & 0.6 & 1.0 & 26.8 & 2.11 & 1.19 \\
\hline
\end{tabular}

velocity $\left(W_{s, 50}\right)$ is computed as follows:

$$
\begin{gathered}
\rho_{\text {floc }}=\rho+C_{\text {int }}\left(\rho_{\text {clay }}-\rho\right) \\
C_{f}=\frac{\left(\rho_{\text {clay }}-\rho\right) C_{i}^{n-1}}{\left(\rho_{\text {floc }}-\rho\right)} \\
d_{e}=L_{f} C_{i}^{F_{m} / 2} \\
L_{f}=\left[\frac{19.8 \rho v \rho_{\text {clay }} F_{k}}{g\left(\rho_{\text {floc }}-\rho\right)}\right]^{1 / 2} \\
D_{*}=d_{e}\left[\frac{g\left(\rho_{\text {floc }}-\rho\right)}{\rho v^{2}}\right]^{1 / 3}
\end{gathered}
$$

$W_{s, 50}=\mathrm{v} / d_{e} \times$

$$
\left[\left(10.36^{2}+1.049\left(1-C_{f}\right)^{4.7} D_{*}^{3}\right)^{0.5}-10.36\right]
$$

where $C_{\text {int }}$ is the internal volume concentration of flocs ( 0.025 to 0.04 , default value is 0.03$), \rho_{\text {clay }}$ is the density of the clay minerals, and $F_{k}$ and $F_{m}$ are two flocculation coefficients with default values 0.001 and 1 (Whitehouse et al., 2000). $F_{k}$ and $F_{m}$ are dependent on the sediment characteristics and likely vary from one stream system to another. In SEDDEER, the user can modify these parameters. No flocculation is calculated below the concentration limit $C_{l l}$, and a simple equation is used between $C_{l l}$ and $C_{u l}$ (default value is $2 \mathrm{~kg} \mathrm{~m}^{-3}$ ): $W_{s, 50}=F_{k} C_{i}^{F m}$. For concentrations between $C_{u l}$ and $50 \mathrm{~kg} \mathrm{~m}^{-3}$, the equations of Whitehouse et al. (2000) are used. These equations are undefined at high concentrations. Thus, the equation $W_{s, 50}=0.00462\left(1-0.01 C_{i}\right)^{3.54}$ is used for concentrations between 50 and $82 \mathrm{~kg} \mathrm{~m}^{-3}$ (van Rijn, 1993), and a constant $W_{s, 50}=10^{-5} \mathrm{~m} \mathrm{~s}^{-1}$ is assumed for concentrations above $82 \mathrm{~kg} \mathrm{~m}^{-3}$.

Even without a unique settling velocity, flocculated particles are still distributed over a certain range (Neumeier et al., 2008). McAnally and Mehta (2001) suggested that the simulation of multi-class fine sediment will produce more realistic results than single-class calculations in estuaries where sediment exhibits a high degree of cohesion and variability in flow-induced shearing.

SEDDEER simulates this range by calculating a new $W_{s(i) F l o c}$ for each original $W_{s(i)}$ such that (Neumeier et al., 2008):

$$
W_{s(i) \text { Floc }}=W_{s F l o c} \sqrt{W_{s(i)} / W_{\text {sMean }}}
$$

where $W_{s(i)}$ is the original settling velocity of the $i$ th settling velocity $\left(W_{s}\right)$ class, $W_{s(i) F l o c}$ is the corrected settling velocity of the $i$ th $W_{s}$ class, and $W_{\text {sMean }}$ is the long-term settling velocity of the original distribution. $W_{\text {sMean }}$ is computed with: 


$$
\log \left(W_{\text {sMean }}\right)=\frac{\sum C_{i} \log \left(W_{s(i)}\right)}{\mathrm{SSC}}
$$

where SSC is the total suspended sediment concentration. This produces a distribution with a log-mean value equal to $W_{s F l o c}$ and a shape similar to that of the original distribution.

Salinity has significant impacts on flocculation and settling velocity of sediment in estuaries. Specifically, salinity influences the consolidation rate, density, and strength of floc within a particular range. The settling velocity of floc increases rapidly with salinity within the range of low salinity; beyond a certain value, salinity will not change the settling velocity much (Chien and Wan, 1983). Migniot (1968) observed that the settling velocity remained constant at salinities of about $3 \mathrm{ppt}$ for low clay concentrations and above $10 \mathrm{ppt}$ for high concentrations. In conditions of constant salinity, settling velocity of floc increases faster with salinity at higher sediment concentration than at lower sediment concentration (Chien and Wan, 1983). Hence, as a first approximation, a settling velocity increasing limiting function for salinity, $f(\mathrm{Sa})$, was embedded in SEDDEER as:

$$
f(S a)=\left\{\begin{array}{cc}
1 & S a \geq S a_{\max } \\
\frac{S a}{K_{S a}+S a} & S a_{\text {min }} \leq S a<S a_{\text {max }} \\
N / A & S a<S a_{\text {min }}
\end{array}\right.
$$

where $K_{S a}$ is the half saturation salinity (ppt), $S a_{\min }$ is the reference minimum salinity $\left(S a_{\min }=0.10 \mathrm{ppt}\right)$, and $S a_{\max }$ is the sediment concentration related saturation salinity above which the settling velocity will not change appreciably (ppt).

In addition, SEDDEER addresses parameters in a more precise manner than previous models. It computes water density and viscosity based on three parameters: temperature, salinity, and concentration of total suspended sediment. Wave and current interact to generate a shear stress that varies in magnitude and direction. SEDDEER calculates the combined shear stress (Ji, 2008) using:

$$
\vec{\tau}_{b}=\vec{\tau}_{c c}+\vec{\tau}_{w w}
$$

where $\vec{\tau}_{b}$ is the (combined wave-current) bottom shear stress, $\vec{\tau}_{c c}$ is the bottom shear stress due to current, and $\vec{\tau}_{w w}$ is the bottom shear stress due to wave. The detailed formulations of $\vec{\tau}_{c c}$ and $\vec{\tau}_{w w}$ can be found in Xiong (2010). In sediment-laden flow, the value of the von Karman constant is usually not the same as that in clear water. Previous efforts in probing the von Karman constant can be found in Chien and Wan (1983) and McAnally (2000). However, the following empirical equation is used to calculate the von Karman constant in SEDDEER:

$$
\kappa=\kappa_{0}-1.68\left(0.365-C_{V}\right) \sqrt{C_{V}}
$$

where $\kappa$ is the von Karman constant, $\kappa_{0}$ is the reference von Karman constant in clear water $\left(\kappa_{0}=0.40\right)$, and $C_{V}$ is the volume fraction of cohesive sediment (and floc). The value calculated with equation 18 is used by SEDDEER in the calculation of near-bed cohesive sediment concentration. A detailed explanation for this expression is presented by Xiong (2010).

When the bed shear stress is greater than the critical shear stress for erosion, surface erosion occurs ( $\mathrm{Ji}, 2008)$. The surface erosion rate of the $i$ th sediment class, $E_{s i}\left(\mathrm{~kg} \mathrm{~m}^{-2} \mathrm{~s}^{-1}\right)$, can be calculated using the well-known Ariathurai-Partheniades equation:

$$
\begin{array}{cc}
E_{s i}=0, & \tau_{b} \leq \tau_{c e, s} \\
E_{s i}=\varepsilon_{M i, s}\left(\frac{\tau_{b}-\tau_{c e, s}}{\tau_{c e, s}}\right), & \tau_{b}>\tau_{c e, s}
\end{array}
$$

where $\varepsilon_{M i, s}$ is the surface erosion rate constant of the $i$ th sediment class $\left(\mathrm{kg} \mathrm{m}^{-2} \mathrm{~s}^{-1}\right)$ (eq. 20), and $\tau_{c e, s}$ is the critical shear stress for surface erosion $\left(\mathrm{N} \mathrm{m}^{-2}\right)$. In equation $19, \varepsilon_{M i, s}$ may be expressed as:

$$
\varepsilon_{M i, s}=f_{M i, s} \varepsilon_{M, s}
$$

where $f_{M i, s}$ is the surface erosion rate constant fraction of the $i$ th sediment class, which depends on factors such as temperature, water viscosity, thickness of the viscous sublayer, "hiding and exposure" effects, and cohesion force; and $\varepsilon_{M, s}$ is the overall surface erosion rate constant $\left(\mathrm{kg} \mathrm{m}^{-2}\right.$ $\mathrm{s}^{-1}$ ). Hwang and Mehta (1989) reported the range of the surface erosion rate constant as 0.005 to $0.10 \mathrm{~g} \mathrm{~s}^{-1} \mathrm{~m}^{-3}$. The $\varepsilon_{M, s}$ value generally decreases while bulk density increases.

Based on experimental observations, Hwang and Mehta (1989) proposed a relationship for the surface erosion rate $\varepsilon_{M, s}\left(\mathrm{mg} \mathrm{h}^{-1} \mathrm{~cm}^{-2}\right)$ :

$$
\varepsilon_{M, S}=\exp \left[0.23 \exp \left(\frac{0.198}{\rho_{b}-1.0023}\right)\right]
$$

where $\rho_{b}$ is the bulk density $\left(\mathrm{g} \mathrm{cm}^{-3}\right)$.

Similar to other sediment transport models, the sediment bed in SEDDEER is subdivided into several sediment layers (maximum of 17). Each layer is considered homogeneous, well mixed, and characterized by its own grain size distribution (fraction of each class of sediment considered). The bed layer type, layer thickness, porosity, dry bulk density, median sediment size $\left(d_{50}\right)$, and critical shear stress for both surface erosion and mass erosion are defined for each layer. If a layer is completely eroded, it is removed and the remaining layers move upward. If a layer is partially eroded, the bed layer characteristics are unchanged. When deposition occurs, the thickness of the uppermost layer increases and the bed layer characteristics are updated accordingly. When the thickness of the uppermost layer reaches a defined limit, a new layer is added to the top. If the number of bed layers equals or exceeds the maximum value, the extra bed layers are removed.

\section{Contaminant Model}

The fate and decay of a particular contaminant can result from physical, chemical, and/or biological reactions. In ad- 
dition to sorption and desorption, processes including mineralization and decomposition, hydrolysis, photolysis, biodegradation, volatilization, wet/dry deposition, bio-uptake, and bio-concentration can significantly affect contaminant fate and decay. A net degradation coefficient considering all the above processes except volatilization is expected to be specified instead of loss/gain coefficients for individual processes.

Assuming a well-mixed water column box, the SEDDEER mass balance equation for a contaminant can be written as (Chapra, 1997; Shrestha and Orlob, 1996):

$$
\begin{aligned}
\frac{d C_{T}^{\text {wat }} H_{\text {wat }}}{d t}= & \frac{Q_{\text {in }}}{A_{\text {wat }}} C_{\text {in }}^{\text {wat }}-\frac{Q_{\text {out }}}{A_{\text {wat }}} C_{T}^{\text {wat }}+W_{L} \\
& +\frac{d\left(\Delta M_{e r}-\Delta M_{\text {de }}\right)}{d t}-F_{\text {wat } / \text { sed }} \\
& +F_{\text {biow }}-k_{\text {wat }} H_{\text {wat }} C_{T}^{\text {wat }} \\
& -k_{\text {vol }} H_{\text {wat }}\left(C_{\text {diss }}^{\text {wat }}-\frac{C_{a}}{\frac{H_{e^{\prime}}}{R T_{K}}}\right)
\end{aligned}
$$

where $C_{T}^{\text {wat }}$ is the total contaminant concentration in the water column $\left(\mu \mathrm{g} \mathrm{L}^{-1}\right), C_{i n}^{\text {wat }}$ is the inflow contaminant concentration $\left(\mu \mathrm{g} \mathrm{L}^{-1}\right), W_{L}$ is the contaminant load per unit area $\left(\mu \mathrm{g} \mathrm{m}^{-1} \mathrm{~L}^{-1} \mathrm{~s}^{-1}\right), \Delta M_{d e}$ is the deposited contaminant mass per unit area $\left(\mu \mathrm{g} \mathrm{m}^{-1} \mathrm{~L}^{-1}\right), \Delta M_{e r}$ is the eroded contaminant mass per unit area $\left(\mu \mathrm{g} \mathrm{m}^{-1} \mathrm{~L}^{-1}\right), F_{\text {watsed }}$ is the mass transfer rate between water and the top sediment bed layer per unit area $\left(\mu \mathrm{g} \mathrm{m}^{-1} \mathrm{~L}^{-1} \mathrm{~s}^{-1}\right), F_{\text {biow }}$ is the mass transfer rate between the top sediment bed layer and water column per unit area due to bioturbation $\left(\mu \mathrm{g} \mathrm{m}^{-1} \mathrm{~L}^{-1} \mathrm{~s}^{-1}\right), k_{\text {wat }}$ is the lumped contaminant loss rate constant in the water column except for volatilization $\left(\mathrm{s}^{-1}\right), k_{v o l}$ is the volatilization rate $\left(\mathrm{s}^{-1}\right), C_{\text {diss }}^{\text {wat }}$ is the freely dissolved contaminant concentration in the water column $\left(\mu \mathrm{g} \mathrm{L}^{-1}\right), C_{a}$ is the atmospheric contaminant concentration $\left(\mu \mathrm{g} \mathrm{L}^{-1}\right), H_{e^{\prime}}$ is Henry's law constant (atm m ${ }^{-3}$ $\left.\mathrm{mol}^{-1}\right), R$ is the universal gas constant $\left(8.206 \times 10^{-5} \mathrm{~atm} \mathrm{~m}^{-3}\right.$ $\mathrm{mol}^{-1} \mathrm{~K}^{-1}$ ), and $T_{K}$ is the absolute temperature $(\mathrm{K})$. The mass balance equation for the top sediment bed layer can be expressed as:

$$
\begin{aligned}
\frac{d C_{T}^{\text {sed } 1} H_{1}}{d t}= & -\frac{d\left(\Delta M_{e r}-\Delta M_{d e}\right)}{d t}+F_{\text {wat } / \text { sed }} \\
& +F_{\text {sed } / \text { sed }}+F_{\text {bio }}-F_{\text {biow }}-k_{\text {sed }} H_{1} C_{T}^{\text {sed } 1}
\end{aligned}
$$

where $C_{T}^{\text {sed } 1}$ is the total contaminant concentration in the top sediment bed layer $\left(\mu \mathrm{g} \mathrm{L}^{-1}\right), H_{1}$ is the thickness of the top sediment bed layer $(\mathrm{m}), F_{\text {sed/sed }}$ is the mass transfer rate between sediment bed layers per unit area $\left(\mu \mathrm{g} \mathrm{m}^{-1} \mathrm{~L}^{-1} \mathrm{~s}^{-1}\right)$, $F_{b i o}$ is the mass transfer rate between sediment bed layers per unit area due to bioturbation $\left(\mu \mathrm{g} \mathrm{m}^{-1} \mathrm{~L}^{-1} \mathrm{~s}^{-1}\right)$, and $k_{\text {sed }}$ is the lumped contaminant loss rate constant in the top sediment bed layer $\left(\mathrm{s}^{-1}\right)$. The mass balance equation for other sediment bed layers can be written as:

$$
\frac{d C_{T}^{\text {sedib }} H_{i b}}{d t}=-F_{\text {sed } / \text { sed }}-F_{\text {bio }}-k_{\text {sed }} H_{i b} C_{T}^{\text {sedib }}
$$

where $C_{T}^{\text {sedib }}$ is the total contaminant concentration in the $i b$ th sediment bed layer $\left(\mu \mathrm{g} \mathrm{L}^{-1}\right)$, and $H_{i b}$ is the thickness of the $i b$ th sediment bed layer $(\mathrm{m})$.

Many previous contaminant models do not take the bioturbation process into account. In this study, we use $F_{\text {biow }}$ and $F_{\text {bio }}$ (as shown in eqs. 22, 23, and 24) to describe the process in sediment bed layers. This process can be represented with the biodiffusion equation:

$$
\begin{gathered}
F_{\text {biow }}=\frac{k_{\text {bio }}}{H_{L w}}\left(C_{T}^{\text {sed } 1}-C_{T}^{\text {wat }}\right) \\
F_{\text {bio }}=\frac{k_{\text {bio }}}{H_{L}}\left(C_{T}^{\text {sed }}(i b+1)-C_{T}^{\text {sedib }}\right)
\end{gathered}
$$

where $k_{b i o}$ is the biodiffusion coefficient $\left(\mathrm{m}^{2} \mathrm{~s}^{-1}\right), H_{L w}$ is the distance between the center and the surface of the top sediment layer $(\mathrm{m}), H_{L}$ is the distance between the centers of the two adjacent sediment layers $i b$ and $i b+1(\mathrm{~m})$, and $C_{T}^{\text {sed }(i b+1)}$ is the total contaminant concentration in the $(i b+1)$ th sediment bed layer $\left(\mu \mathrm{g} \mathrm{L} \mathrm{L}^{-1}\right)$.

SEDDEER also updates the total contaminant concentration in each sediment bed layer due to bed consolidation. As the sediment bed is squeezed and becomes firmer, pore water is expelled because of bed consolidation. Moreover, floc is intact, as assumed earlier. Based on these assumptions, the updated total contaminant concentration in the sediment bed layer is expressed as:

$C_{T}^{\text {sedib } 1}=\frac{H_{i b}^{0}\left[C_{\text {part }}^{\text {sedib } 0}+\left(C_{\text {diss }}^{\text {sedib } 0}+C_{D O C}^{\text {sedib } 0}\right) \frac{n_{\text {sedib }}^{1}}{n_{\text {sedib }}^{0}}\right]}{H_{i b}^{1}}$

where $C_{T}^{\text {sedib1 }}$ is the updated total contaminant concentration in the $i b$ th sediment bed layer $\left(\mu \mathrm{g} \mathrm{L}^{-1}\right), H_{i b}^{0}$ is the original thickness of the $i b$ th sediment bed layer (m), $C_{\text {part }}^{\text {sedib0 }}$ is the original sediment-associated contaminant concentration in the $i b$ th sediment bed layer $\left(\mu \mathrm{g} \mathrm{L}{ }^{-1}\right), C_{d i s s}^{\text {sedib0 }}$ is the original freely dissolved contaminant concentration in the $i b$ th sediment bed layer $\left(\mu \mathrm{g} \mathrm{L}^{-1}\right), C_{D O C}^{\text {sedib0 }}$ is the original DOCcomplexed contaminant concentration in the $i b$ th sediment bed layer $\left(\mu \mathrm{g} \mathrm{L}^{-1}\right), n_{\text {sedib }}^{1}$ is the updated porosity of the $i b$ th sediment bed layer, $n_{\text {sedib }}^{0}$ is the original porosity of the $i b$ th sediment bed layer, and $H_{i b}^{1}$ is the updated thickness of the $i b$ th sediment bed layer (m). Consequently, the water column gains the contaminant squeezed out from the sediment bed, and the updated total contaminant in the water column is given as: 
$C_{T}^{\text {wat } 1}=$

$C_{T}^{\text {wat } 0}+\frac{\sum_{i b=1}^{N B E D}\left[H_{i b}^{0}\left(C_{\text {diss }}^{\text {sedib0 }}+C_{D O C}^{\text {sedib0 }}\right)\left(1-\frac{n_{\text {sedib }}^{1}}{n_{\text {sedib }}^{0}}\right)\right]}{H_{\text {wat }}}$

where $C_{T}^{\text {wat } 1}$ is the updated total contaminant concentration in the water column $\left(\mu \mathrm{g} \mathrm{L}^{-1}\right)$, and $C_{T}^{\text {wat0 }}$ is the original total contaminant concentration in the water column $\left(\mu \mathrm{g} \mathrm{L}^{-1}\right)$.

\section{SEDDEER CODE}

SEDDEER has been written in two languages. SEDDEER for VBA (SEDDEER_VBA) is written in Microsoft Office macro language (Visual Basic for Application, VBA), and Microsoft Excel is used as the graphical interface. SEDDEER for FORTRAN (SEDDEER_FOR) is the corresponding model programmed in FORTRAN.

In SEDDEER, the equations corresponding to erosion, settling, deposition, bed reformulation after erosion, bed reformulation after deposition, consolidation, etc., were coded into different subroutines. Although contaminant partitioning and kinetics were isolated from the main program for later improvement, the whole contaminant model is not in a separate subroutine but embedded in the main calculation loop of the transport processes. Thus, considering the sediment and contaminant processes, contaminant masses and concentrations in various phases (freely dissolved, sediment-associated, and dissolved oxygen carbon (DOC) complexed) in both the water column and sediment bed are updated at the end of each time step.

\section{MODEl TEST APPROACHES}

Model tests were performed to validate SEDDEER's algorithms by checking mass balance, comparing SEDDEER output to measured data, and comparing it to the output of a reputable model (EFDC; Environmental Fluid Dynamics Code). A mass balance check of the primary sediment and contaminant was done since mass conservation is the basic principle of both the sediment transport and water quality models. Whether mass is conserved or not was checked for both the primary sediment and contaminant.

A partial validation of SEDDEER was carried out by comparing model results with data from experiments and site measurements published in the literature. As mentioned before, SEDDEER contains the following main processes: deposition, resuspension, consolidation, sediment bed processes, and one contaminant process. SEDDEER also considers the effects of sediment concentration on settling velocity, bottom shear stress, von Karman constant, etc., making it a more complete model than is commonly used by the sediment modeling community. These qualities limit the comparisons between SEDDEER simulation results and analytical solutions or other model's results. For brevity, this article shows only the verification and validation approaches for the major sediment processes (settling and deposition) and the contaminant transport algorithms. The reader is encouraged to review Xiong (2010) for a detailed account of the development and verification of other minor processes included in the SEDDEER model.

\section{Validation of Settling and Deposition}

To verify settling and deposition, suspended and bed sediment concentrations along with mass of sediment (and floc) classes with different sediment sizes were calculated. Verification and validation of settling with sediment concentrations greater than the lower concentration limit for flocculation-enhanced settling were also performed.

The conservation of floc mass was verified, initially. The initial sediment concentration was set to $2.00 \mathrm{~kg} \mathrm{~m}^{-3}$, while the initial contaminant concentration was set to $1.00 \mu \mathrm{g} \mathrm{L}^{-1}$ in the water column and $0.00 \mu \mathrm{g} \mathrm{g}^{-1}$ in the sediment bed. Due to the high sediment concentration used in this test, all sediments would flocculate to form flocs and aggregates and then undergo flocculation settling.

Mehta (1973) and Maa et al. (2008) carried out deposition experiments using commercially available kaolinite with a median diameter $\left(d_{50}\right)$ of $4.00 \mu \mathrm{m}$. Therefore, to validate the settling and deposition processes, SEDDEER modeling results (represented by eqs. 1 to 18 ) were compared with the experimental results obtained by Mehta (1973) and Maa et al. (2008). Experimental data for the averaged bed shear stress at $0.85 \mathrm{~Pa}$ (table 2) were extracted from Mehta (1973). Mehta's experiment was conducted in a rotating annular flume consisting of a circular channel. The channel was $0.45 \mathrm{~m}$ deep with a mean diameter of $1.50 \mathrm{~m}$ and an annular ring of the same mean diameter as the channel (Mehta, 1973). The deposition tests were carried out using a variety of mud types, including San Francisco Bay mud (Krone, 1962, cited by Mehta, 1973). Mud was added to the flume with a high flow velocity to mix it thoroughly before the shear stress was reduced below the critical level for deposition. The initial mud concentrations were $1.00 \mathrm{~kg} \mathrm{~m}^{-3}$.

The observed data for the test scenarios with shear stresses of $0.00,0.05$, and $0.50 \mathrm{~Pa}$ (table 2) were taken from Maa et al. (2008). In that study, experiments were conducted at Choubuk National University, South Korea, to mimic the deposition test carried out by Mehta (1973). Like Mehta (1973), an annular flume was also used in this experiment and had the following dimensions: channel depth $=0.10 \mathrm{~m}$, inner wall radius $=1.00 \mathrm{~m}$, and outer wall radius $=1.15 \mathrm{~m}$. The averaged bed shear stresses were obtained by adjusting the ring rotation speed.

In this research, two settling models were validated: combined Teeter (2001) and Whitehouse et al. (2000) (designated T-W), and combined Shrestha and Orlob (1996)

Table 2. Deposition of cohesive sediments. SEDDEER uses size ranges to define the primary sediment classes.

\begin{tabular}{lc}
\hline Parameters and Constants & Values \\
\hline Sediment size classes $\left(d_{i l}\right.$ to $\left.d_{i u}, \mathrm{~m}\right)$ & 0 to $3.1 \times 10^{-5}$ [a] \\
Primary sediment density $\left(\rho_{s}, \mathrm{~kg} \mathrm{~m}^{-3}\right)$ & 2600 \\
Initial sediment conc. in water column $\left(\mathrm{kg} \mathrm{m}^{-3}\right)$ & 1.00 \\
Water depth $\left(H_{\text {wat }}, \mathrm{m}\right)$ & 0.45 \\
Sediment bed porosity $\left(n_{\text {sed }}\right)$ & 0.50 \\
Initial sediment bed layer mass fraction & $1.00^{[\mathrm{b}]}$ \\
Shear stress $\left(\tau_{b}, \mathrm{~Pa}\right)$ & $0.00,0.05,0.50,0.85$ \\
\hline [a] Class 0 to $3.1 \times 10^{-5}$ indicates a sediment class with sediment size $\leq 3.1$ \\
$\quad \times 10^{-5} \mathrm{~m}$; 15 classes of flocs were specified for this deposition test. \\
[b] Only one primary sediment class.
\end{tabular}


Table 3. Parameters and constants for DDE and lindane verification and validation.

\begin{tabular}{|c|c|c|c|}
\hline \multicolumn{2}{|l|}{ Input Parameters } & DDE & Lindane \\
\hline \multicolumn{4}{|l|}{ Segmentation parameters } \\
\hline \multirow[t]{2}{*}{ Water column } & Water depth $\left(H_{\text {wat }}, \mathrm{m}\right)$ & \multicolumn{2}{|c|}{13.9} \\
\hline & Flow velocity $\left(u, \mathrm{~m} \mathrm{~s}^{-1}\right)$ & \multicolumn{2}{|c|}{$\sim 0$} \\
\hline \multirow[t]{3}{*}{ Benthic sediment } & Surface benthic layer depth $\left(H_{1}, \mathrm{~m}\right)$ & 0.015 & 0.015 \\
\hline & Subsurface benthic layer depth $\left(H_{2}, \mathrm{~m}\right)$ & 0.020 & 0.020 \\
\hline & Third benthic layer depth $\left(H_{3}, \mathrm{~m}\right)$ & 0.020 & 0.020 \\
\hline \multicolumn{4}{|l|}{ System parameters } \\
\hline \multirow[t]{4}{*}{ Water column } & Initial toxicant concentration $\left(C_{T}^{\text {wat }}, \mu \mathrm{g} \mathrm{L}^{-1}\right)$ & 0.00352 & 0.0254 \\
\hline & Sediment concentration $\left(C_{i}, \mathrm{mg} \mathrm{L}^{-1}\right)$ & \multicolumn{2}{|c|}{ Silts and clays (5) } \\
\hline & Sediment loading $\left(W_{i}\right)$ & \multicolumn{2}{|c|}{0} \\
\hline & Toxicant loading $\left(W_{L}\right)$ & 0 & 0 \\
\hline \multirow[t]{7}{*}{ Benthic sediment } & Initial toxicant concentration at top layer $\left(C_{\text {part }}^{\operatorname{sed} 10}, \mu \mathrm{g} \mathrm{g}^{-1}\right)$ & 0.0353 & 0.00187 \\
\hline & Initial toxicant concentration at second layer $\left(C_{\text {part }}^{\text {sed } 20}, \mu \mathrm{g} \mathrm{g}^{-1}\right)$ & 0.0009 & 0.00246 \\
\hline & Initial toxicant concentration at third layer $\left(C_{\text {part }}^{\operatorname{sed} 30}, \mu \mathrm{g} \mathrm{g}^{-1}\right)$ & 0.0009 & 0.00140 \\
\hline & Top sediment layer porosity $\left(n_{\text {sed } 1}\right)$ & 0.70 & 0.70 \\
\hline & Second sediment layer porosity $\left(n_{\text {sed } 2}\right)$ & 0.70 & 0.70 \\
\hline & Third sediment layer porosity $\left(n_{\text {sed } 3}\right)$ & 0.70 & 0.70 \\
\hline & Sediment mass fraction $\left(f r_{M 1}, f r_{M 2}\right)$ & $57 \%$ clay, $43 \%$ silt & $57 \%$ clay, $43 \%$ silt \\
\hline \multirow[t]{12}{*}{ Other constants and parameters } & Molecular weight of the chemical $\left(M W, \mathrm{~g} \mathrm{~mol}^{-1}\right)$ & 318 & 291 \\
\hline & Partition coefficient to silts and clays $\left(K, \mathrm{~L} \mathrm{~kg}^{-1}\right)$ & 1540 & 155 \\
\hline & Henry's law constant $\left(H_{e^{\prime}}\right.$, atm m $\left.{ }^{-3} \mathrm{~mol}^{-1}\right)$ & $3.9 \times 10^{-5}$ & $4.9 \times 10^{-7}$ \\
\hline & Degradation rate (water column/sediment bed) $\left(k_{\text {wat }}, k_{\text {sed }}, \mathrm{s}^{-1}\right)$ & $1.2 \times 10^{-8} / 1.2 \times 10^{-8}$ & $3.2 \times 10^{-8} / 2.9 \times 10^{-8}$ \\
\hline & Volatilization rate $\left(k_{v o l}, \mathrm{~s}^{-1}\right)$ & $1.61 \times 10^{-7}$ & $2.00 \times 10^{-9}$ \\
\hline & Sediment density $\left(\rho_{1}, \rho_{2}, \mathrm{~kg} \mathrm{~m}^{-3}\right)$ & \multicolumn{2}{|c|}{2500} \\
\hline & Sediment settling velocity $\left(w, \mathrm{~m} \mathrm{~s}^{-1}\right)$ & \multicolumn{2}{|c|}{ Calculated } \\
\hline & Critical shear stress for deposition $\left(\tau_{c d}, \mathrm{~N} \mathrm{~m}^{-2}\right)$ & \multicolumn{2}{|c|}{ Calculated } \\
\hline & Critical shear stress for erosion $\left(\tau_{c e}, \mathrm{~N} \mathrm{~m}^{-2}\right)$ & \multicolumn{2}{|c|}{ Calculated } \\
\hline & Diffusion coefficient in sediment bed pore water $\left(k_{\text {sed/sed }}, \mathrm{m}^{2} \mathrm{~s}^{-1}\right)$ & $4.9 \times 10^{-10}$ & $2.45 \times 10^{-10}$ \\
\hline & Sediment-water diffusive transfer coefficient $\left(k_{\text {wat } / \text { sed }}, \mathrm{m} \mathrm{s}^{-1}\right)$ & $3.43 \times 10^{-8}$ & $1.72 \times 10^{-8}$ \\
\hline & Exchange (molecular diffusion coefficient $D_{m}, \mathrm{~m}^{2} \mathrm{~s}^{-1}$ ) & $1.0 \times 10^{-9}$ & $5.0 \times 10^{-10}$ \\
\hline
\end{tabular}

and Whitehouse et al. (2000) (designated S-W). The parameters listed in table 2 were used for the validation.

The values used as input to SEDDEER (table 2) were chosen considering the experiment setups of Mehta (1973) and Maa et al. (2008). By comparing SEDDEER-calculated data to the Mehta (1973) and Maa et al. (2008) experiments, we validated the performance of SEDDEER without resorting to model calibration to fit the experimental data. In addition, an EFDC solution with one sediment class was provided for the test scenario with shear stress of $0.00 \mathrm{~Pa}$ to show SEDDEER's capability for replicating results from other models.

Coefficient of determination $\left(\mathrm{R}^{2}\right)$ values were calculated to assess the goodness-of-fit of model-simulated results to measured data. To further quantitatively describe the accuracy of sediment deposition in model outputs when compared to measured data, the root-mean-square error (RMSE), NashSutcliffe (NS) model efficiency coefficient, and percent bias (PBIAS) (Moriasi et al., 2007) were calculated.

\section{Validation of Contaminant Model}

In order to evaluate the overall performance in modeling contaminant processes, experimental field data reported by Boyer et al. (1994) were compared to SEDDEER model results. Boyer et al. (1994) used DDE (dichlorodiphenyldichloroethylene) and lindane ( $\gamma$-hexachlorocyclohexane) data from a flooded limestone quarry (collected near the town of Oolitic in Bedford County, Indiana) to validate RECOVERY, a time-varying numerical model with a wellmixed surface water layer underlain by a vertically stratified sediment column, based on previous modeling efforts by Di Toro and Paquin (1984). SEDDEER was set up with the same modeling settings provided by Boyer et al. (1994) and Di Toro and Paquin (1984). As described by Boyer et al. (1994) and Di Toro and Paquin (1984), an instantaneous fully mixed water column and sediment layers with no inflow/outflow were assumed so that SEDDEER could be validated in the same way as RECOVERY. In addition, EFDC was set up to mimic the Boyer et al. (1994) and Di Toro and Paquin (1984) experimental and modeling settings. With no volumetric source/sink, EFDC was configured to have only one water cell with a few underlying sediment bed layers (one static, completely mixed water segment simulation). The physical and chemical input parameters and constants in the modeling of DDE and lindane in the flooded limestone quarry are shown in table 3.

\section{Model VAlidation Results} VALIDATION OF SETTLING AND DEPOSITION

Floc consists of the primary sediment and its affixed water. As shown in figure 1, the increased floc mass in the sediment bed equals the sum of primary sediment mass and floc-bound water mass, and the decreased sediment mass in the water column is exactly the same as the increased primary sediment mass in the sediment bed. Furthermore, figure 2 shows that the increased contaminant mass in the sediment bed is equivalent to the decreased contaminant mass in the water column. Thus, the code for flocculation settling is considered validated for mass conservation of both sediment and contaminant.

Figures 3 and 4 show experimental deposition data from Mehta (1973) and Maa et al. (2008) compared to 


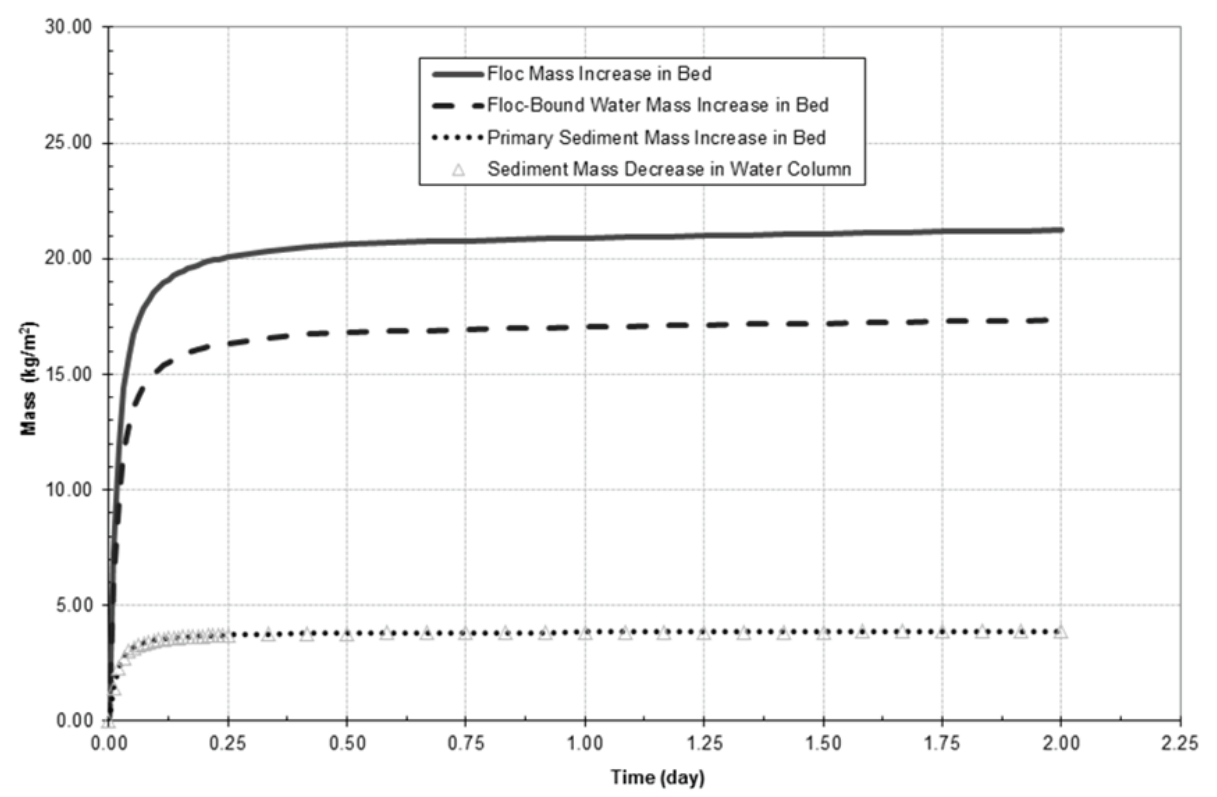

Figure 1. Validation of floc mass conservation. Floc mass and sediment mass are conserved through time.

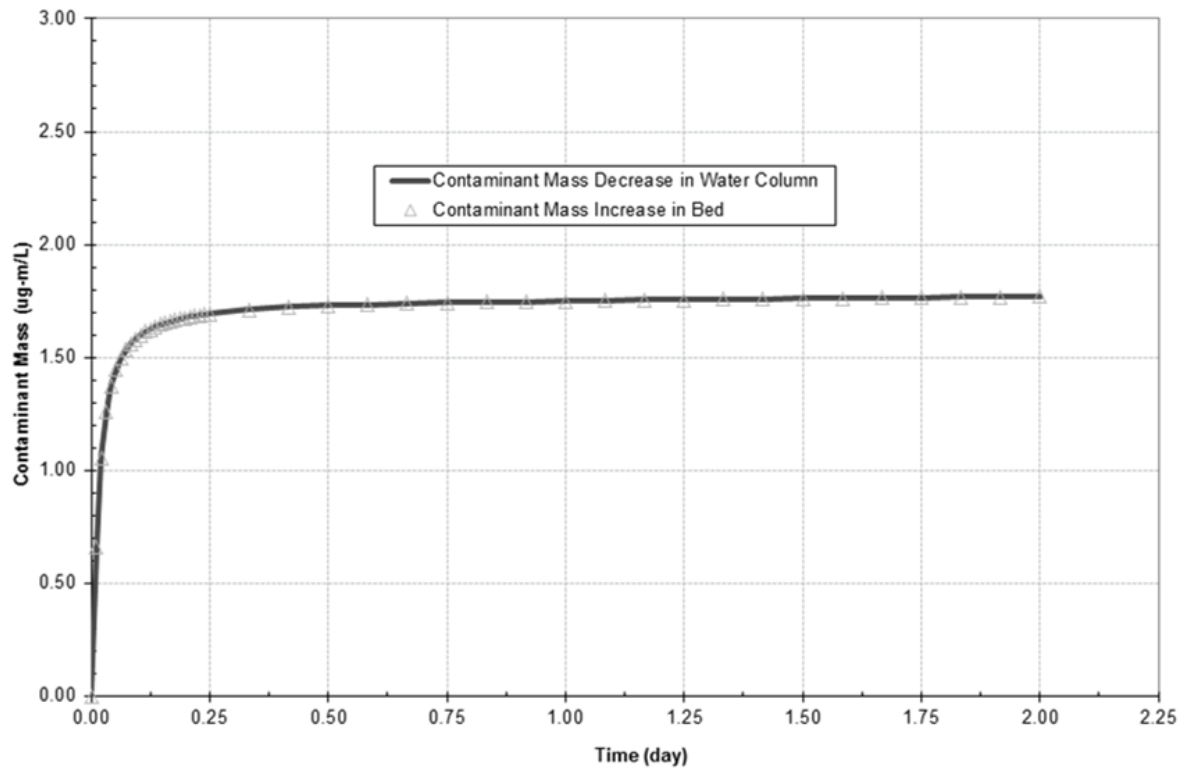

Figure 2. Validation of contaminant mass conservation. Contaminant mass is conserved through time.

SEDDEER-generated deposition data, without calibration of model parameters. For lower shear stress values $(0.00$ and $0.05 \mathrm{~Pa}$ ), SEDDEER reproduces the observed data well; values of $\mathrm{R}^{2}$ range from 0.98 to 1.00 , and NS model fit efficiency ranges from 0.92 to 0.97 . For these low shear stress values, test results show that the model performs acceptably. When the shear stress is set to $0.00 \mathrm{~Pa}$, the SEDDEER-simulated output is statistically equivalent to that of EFDC. However, the EFDC algorithm does not allow specifying multiple floc classes as SEDDEER does.

For higher shear stress values $(0.50$ and $0.85 \mathrm{~Pa})$, although the values of $\mathrm{R}^{2}$ (ranging from 0.53 to 0.63 ) and NS (ranging from -0.52 to 0.18 ) indicate that the SEDDEERsimulated values do not compare well with the observed data, the values of RMSE $(<0.065)$ and PBIAS $(< \pm 15.47 \%)$ show that SEDDEER performs acceptably. In addition, the general trend of the deposition rate is adequately captured by SEDDEER. Krause et al. (2005) made a comparison of nine different fit-efficiency measures including $\mathrm{R}^{2}, \mathrm{NS}$, and PBIAS. They found that, when evaluating model performance, none of the efficiency criteria performed ideally. With NS and $\mathrm{R}^{2}$ being the most used, they state that these indicators are very sensitive to peak values at the expense of better performance for low values. Krause et al. (2005) concluded that each of the criteria has specific pros and cons that have to be taken into account during model calibration and evaluation. Additional comparisons of SEDDEER output to experimental data (that are out of the scope of this article) would give insight into this apparent contradiction. However, as discussed above, these validation results are considered to be satisfactory because the values used as input to SEDDEER (table 2) were not the calibration parameters. 


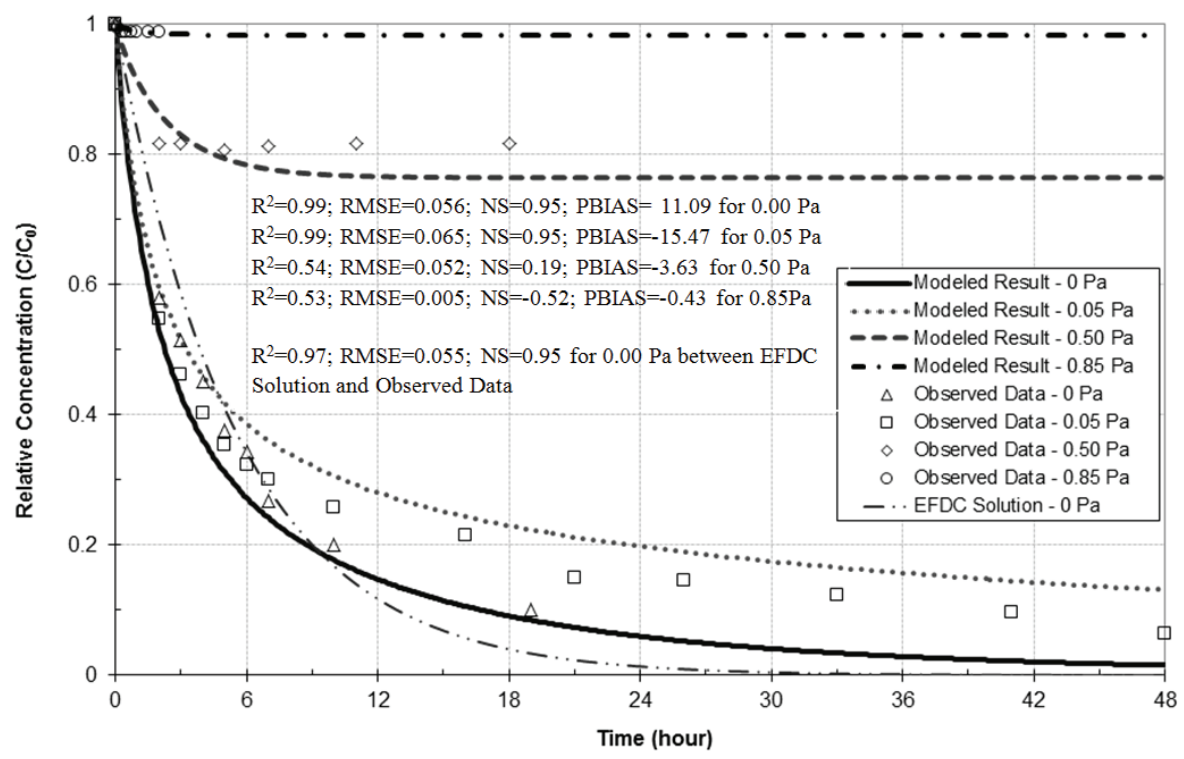

Figure 3. Temporal change in suspended sediment concentration at different shear stress values (combined Teeter and Whitehouse, T-W). Measured and simulated suspended sediment concentrations for bed shear values of $0.85,0.50,0.05$, and $0.00 \mathrm{~Pa}$ are compared.

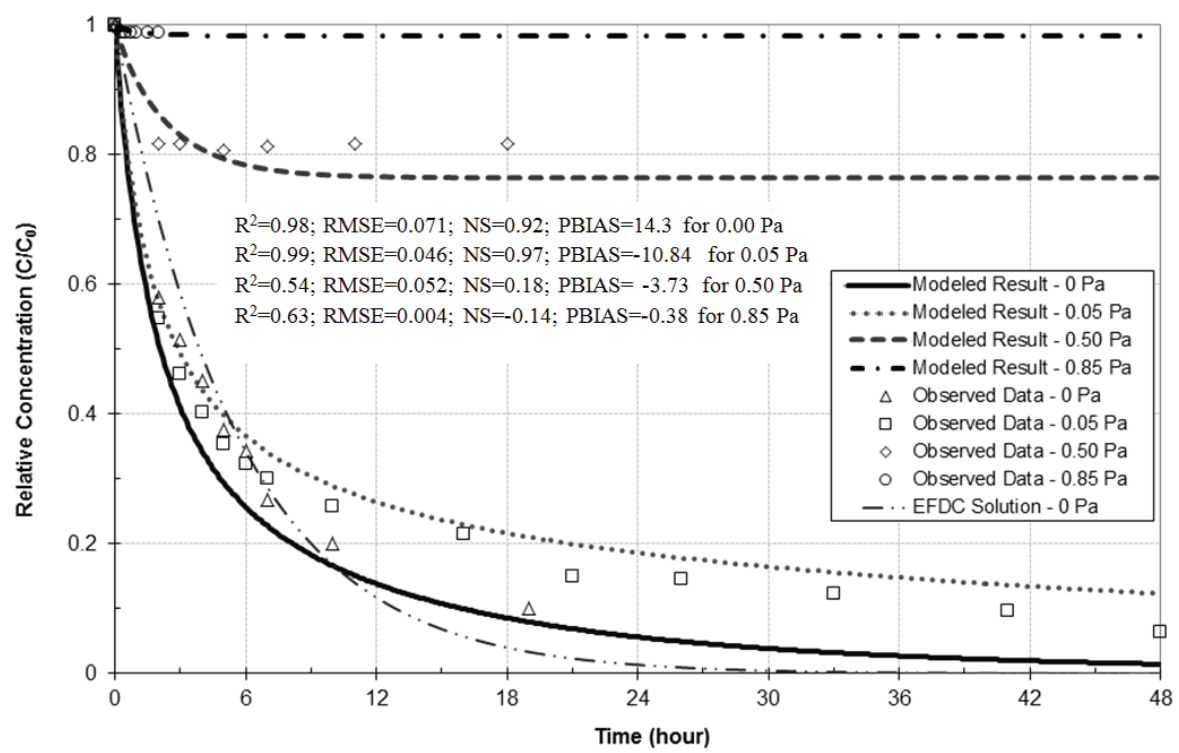

Figure 4. Temporal change in suspended sediment concentration at different shear stresses (combined Shrestha and Orlob and Whitehouse, S-W). Measured and simulated suspended sediment concentrations for bed shear values of $0.85,0.50,0.05$, and 0.00 Pa are compared.

The purpose of the present comparison is to show the robustness of SEDDEER without using calibration strategies.

\section{VALIDATION OF CONTAMINANT MODEL}

Figures 5 and 6 show SEDDEER-simulated results, EFDC results, and field data (Boyer et al., 1994) for DDE in the water column (fig. 5) and in the sediment bed (fig. 6). As shown in figure 5, both SEDDEER and EFDC agree well with the field measurements $\left(\mathrm{R}^{2}=0.94\right)$. The SEDDEER simulation is almost identical to the EFDCcalculated results in the water column because they have the same first-order volatilization and degradation schemes. With regard to DDE in the sediment bed (fig. 6), the SEDDEER results show good agreement with the observed data $\left(\mathrm{R}^{2}=0.74\right)$. Although the SEDDEER and EFDCcalculated DDE concentrations curves show the same trend, there is an almost constant difference of about $1.00 \mu \mathrm{g} \mathrm{L} \mathrm{L}^{-1}$ between the SEDDEER and EFDC concentration values. This is due to the specific sediment bed morphology schemes that the models adopted. Both EFDC and SEDDEER allow the bed layer void ratios and thicknesses to vary in time; however, they have different sediment bed consolidation formulations. Despite this difference, the model fit efficiency between EFDC and SEDDEER is good, as shown by the coefficient of determination $\left(\mathrm{R}^{2}\right)$ of 0.97 .

Lindane field data were not as abundant as the DDE field data in Boyer et al. (1994); therefore, the validation of SEDDEER for lindane relies more on comparisons of SEDDEER output to EFDC output. Lindane simulations in the water column and in the sediment bed are represented in figures 7 and 8, respectively. As shown in figure 7, the SEDDEER-simulated results agree well with the EFDC- 


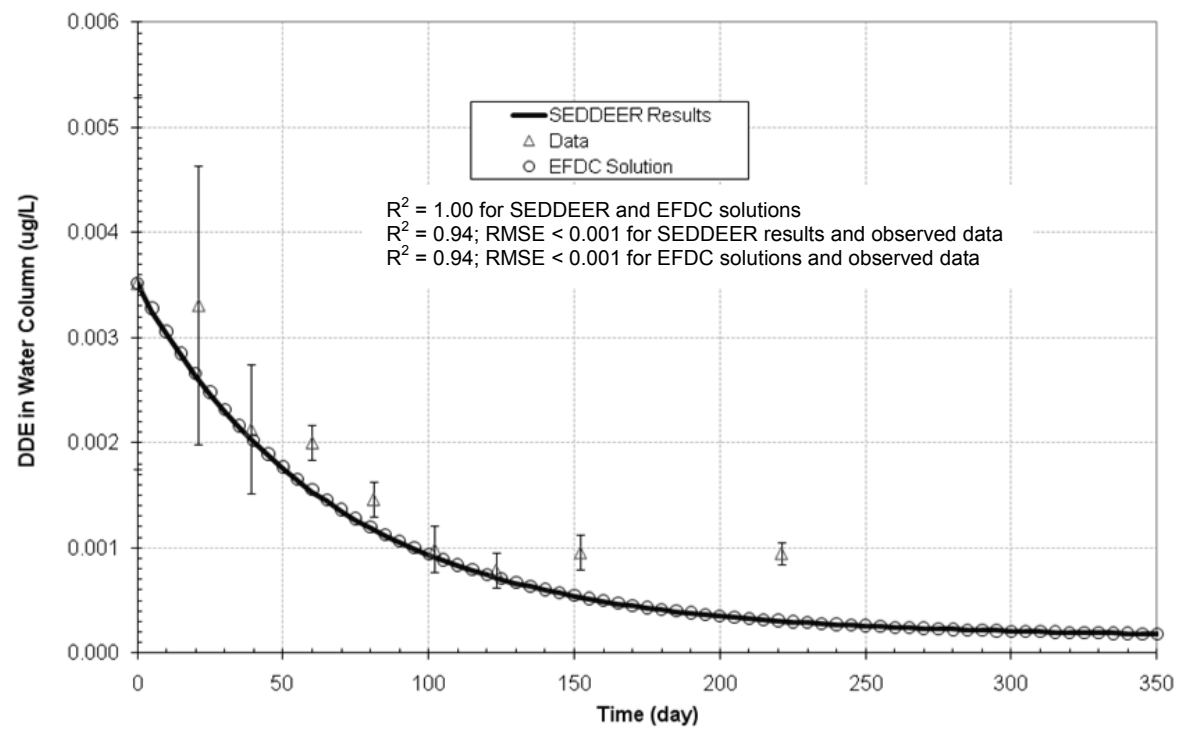

Figure 5. Comparison of measured and simulated dichlorodiphenyldichloroethylene (DDE) concentrations in the water column.

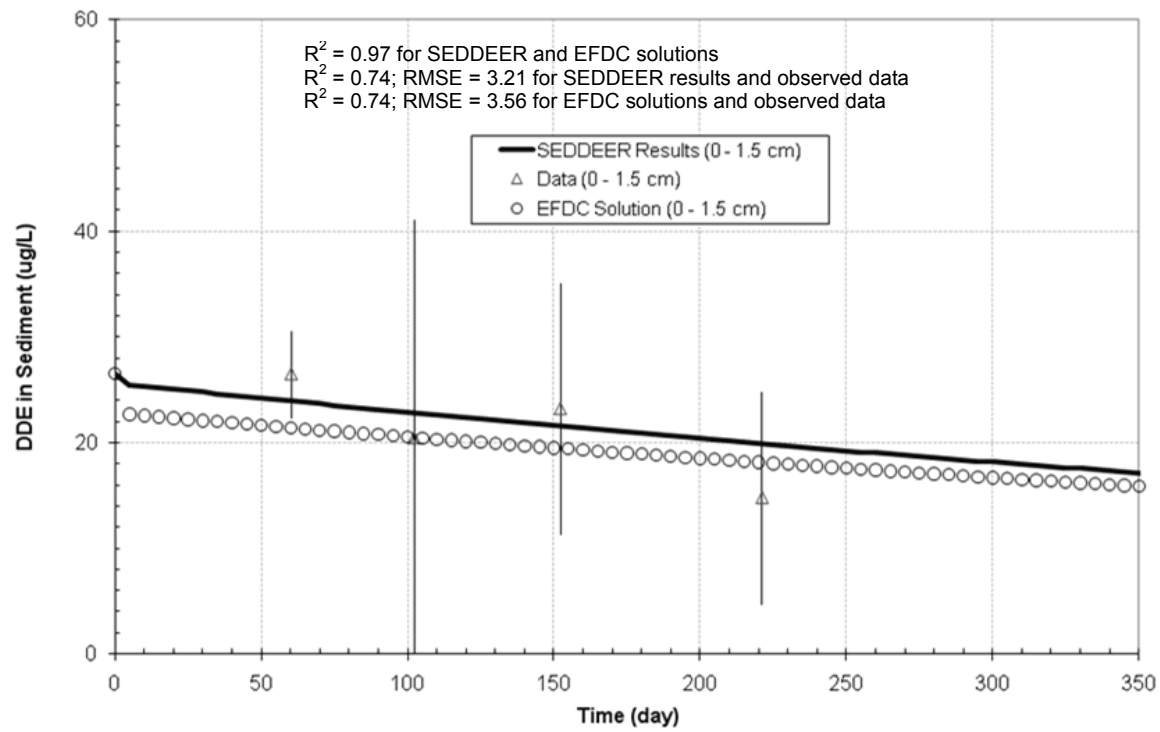

Figure 6. Comparison of measured and simulated dichlorodiphenyldichloroethylene (DDE) concentrations in the sediment bed.

calculated output $\left(\mathrm{R}^{2}=1.00\right)$ and with the observed data $\left(\mathrm{R}^{2}=0.85\right)$ in the water column. There is a consistent difference of $2 \mu \mathrm{g} \mathrm{L}^{-1}$ in the simulation of lindane in the sediment bed (fig. 8) between SEDDEER and EFDC. This is explained by SEDDEER and EFDC having different bed layer algorithms for diffusion within and between sediment bed layers. Nevertheless, the SEDDEER output agrees better than that of EFDC with the field data.

Figures 9 and 10 show the long-term DDE simulations in the water column and the sediment bed, respectively. SEDDEER agrees well with EFDC in the long-term DDE simulation $\left(\mathrm{R}^{2}=1.00\right.$ in sediment bed, and $\mathrm{R}^{2}=0.99$ in water column). This was an expected result because both models have the same first-order volatilization and degradation schemes. SEDDEER simulation of DDE in the sediment bed after approximately five years (1800 days in fig. 10) is within the range of the field data (sample A: 3.40 to $11.20 \mu \mathrm{g} \mathrm{L}^{-1}$; sample $\mathrm{B}: 2.90$ to $4.20 \mu \mathrm{g} \mathrm{L}^{-1}$ ), as described by Di Toro and Paquin (1984), but still a little lower than the average concentration and Di Toro and Paquin's result of $5.60 \mu \mathrm{g} \mathrm{L}^{-1}$.

Long-term lindane simulations in the water column and sediment bed are shown in figures 11 and 12. SEDDEER shows good agreement with EFDC in the long-term lindane simulation for the water column $\left(\mathrm{R}^{2}=1.00\right)$. Again, a minor difference between the SEDDEER and EFDC output for lindane in the sediment bed is observed $\left(\mathrm{R}^{2}=0.97\right)$ for earlier simulation times (time $<1080$ days). Non-identical bed layer algorithms and settings are the reason for this difference.

\section{INCORPORATING SEDDEER_FOR INTO WASP}

Although this article does not detail the actual incorporation of SEDDEER into water quality models, this section presents a summarized account of how SEDDEER was incorporated into the Water Quality Simulation Program (WASP). The reader is referred to Xiong (2010) and Xiong et al. (2010) for a thorough description of this implementation.

WASP suspended sediment simulation is based on an integrated control volume equation (Chapra, 1997): 


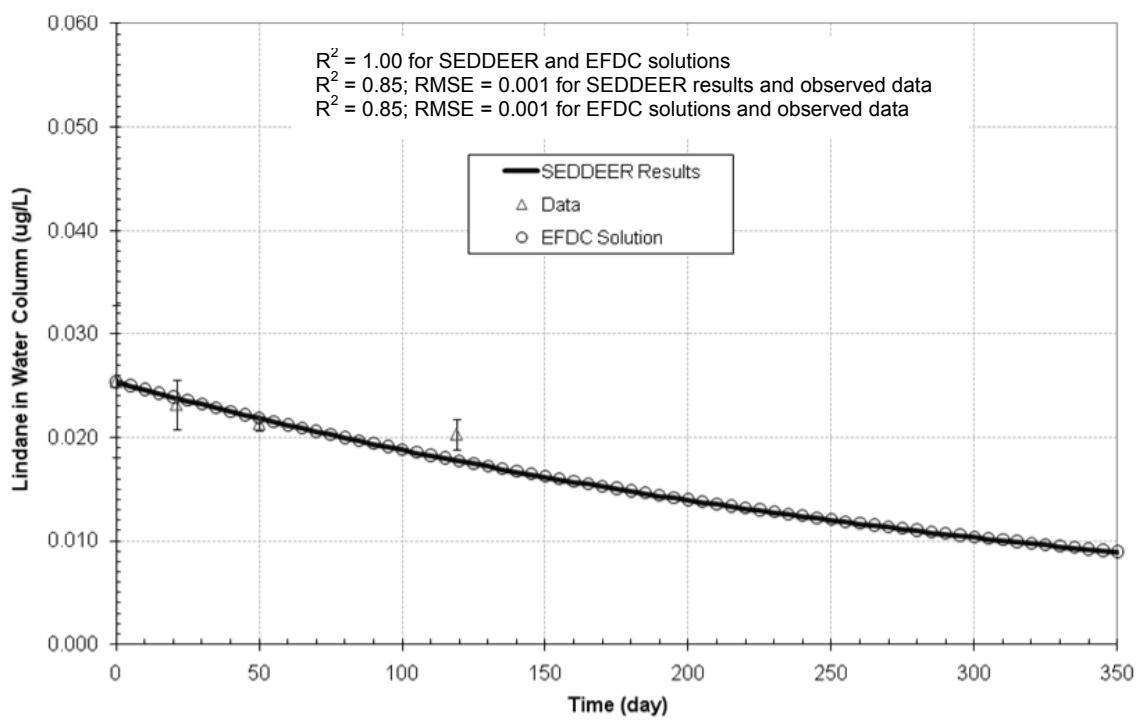

Figure 7. Comparison of measured and simulated lindane in the water column.

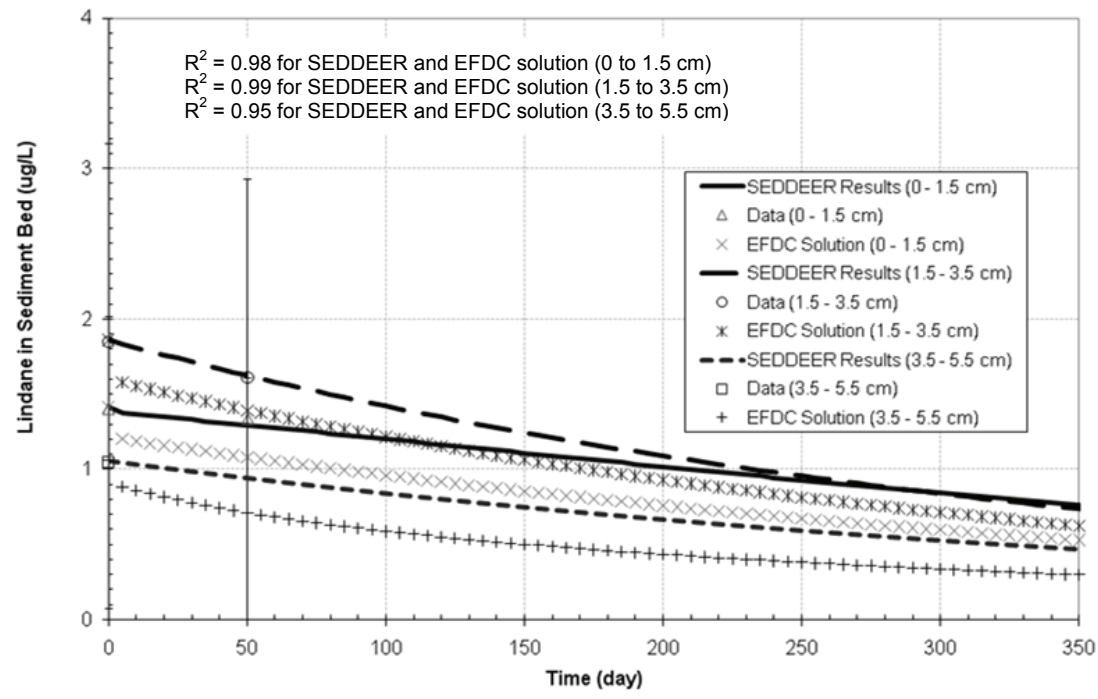

Figure 8. Comparison of measured and simulated lindane in the sediment bed.

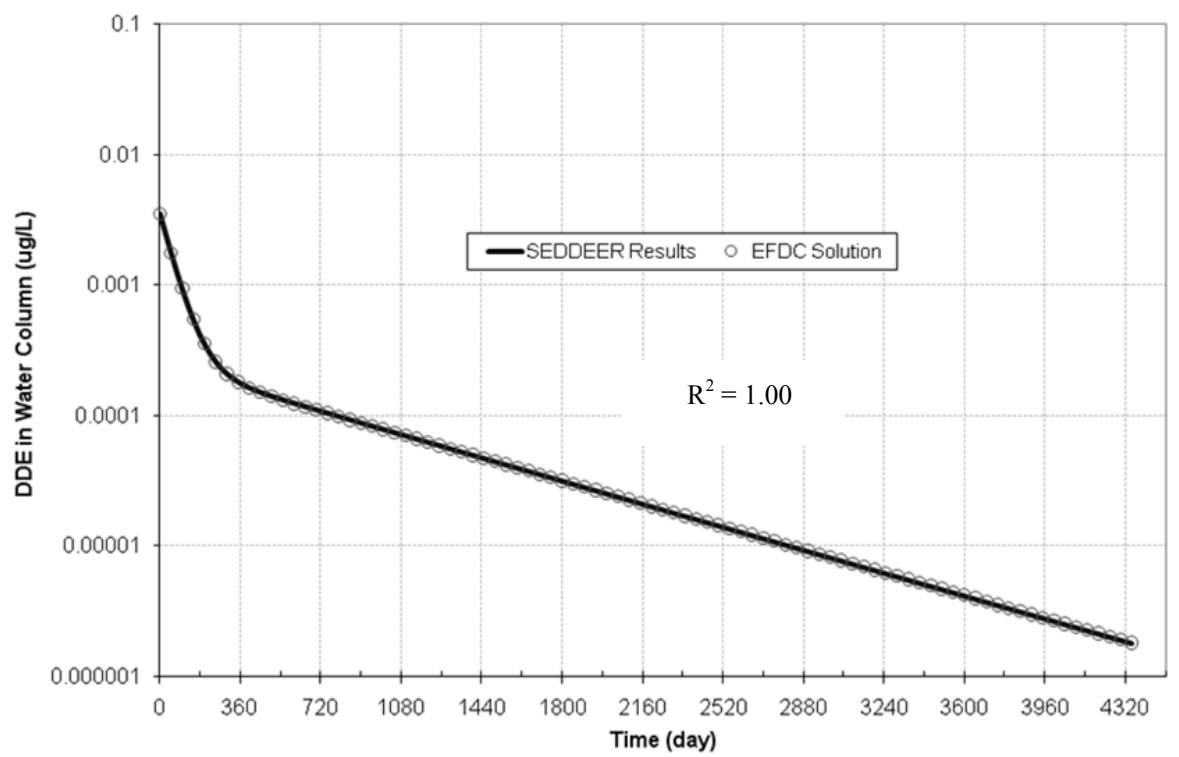

Figure 9. Long-term simulation of dichlorodiphenyldichloroethylene (DDE) in the water column. 


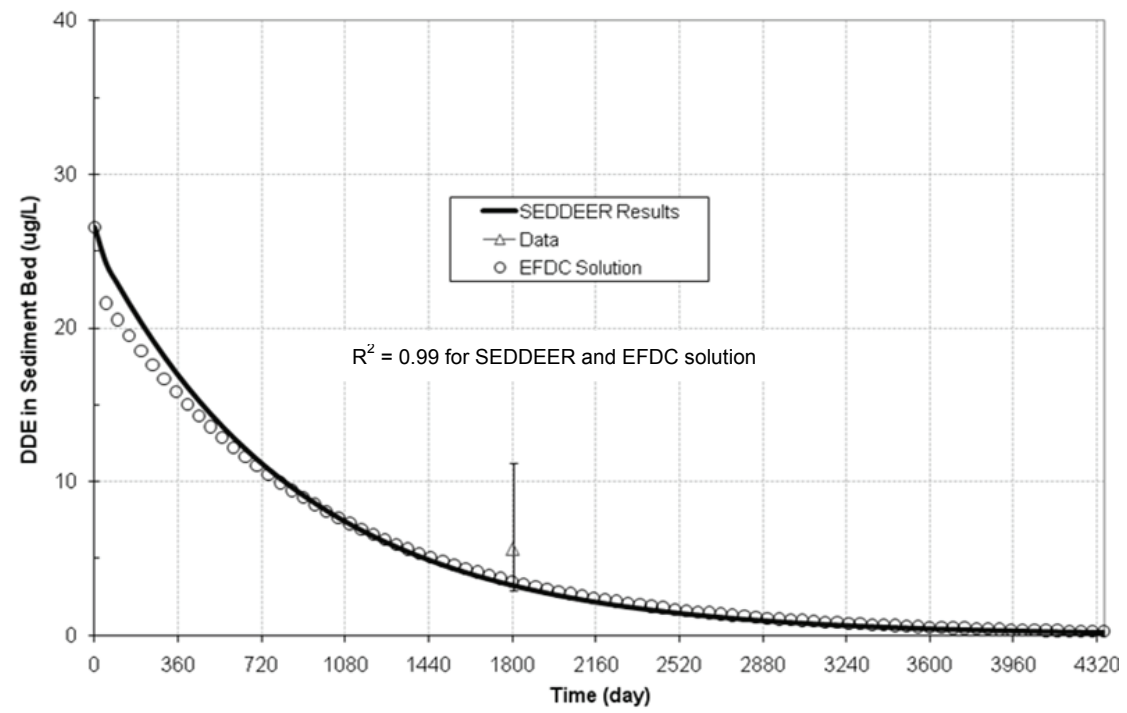

Figure 10. Long-term simulation of dichlorodiphenyldichloroethylene (DDE) in the sediment bed.

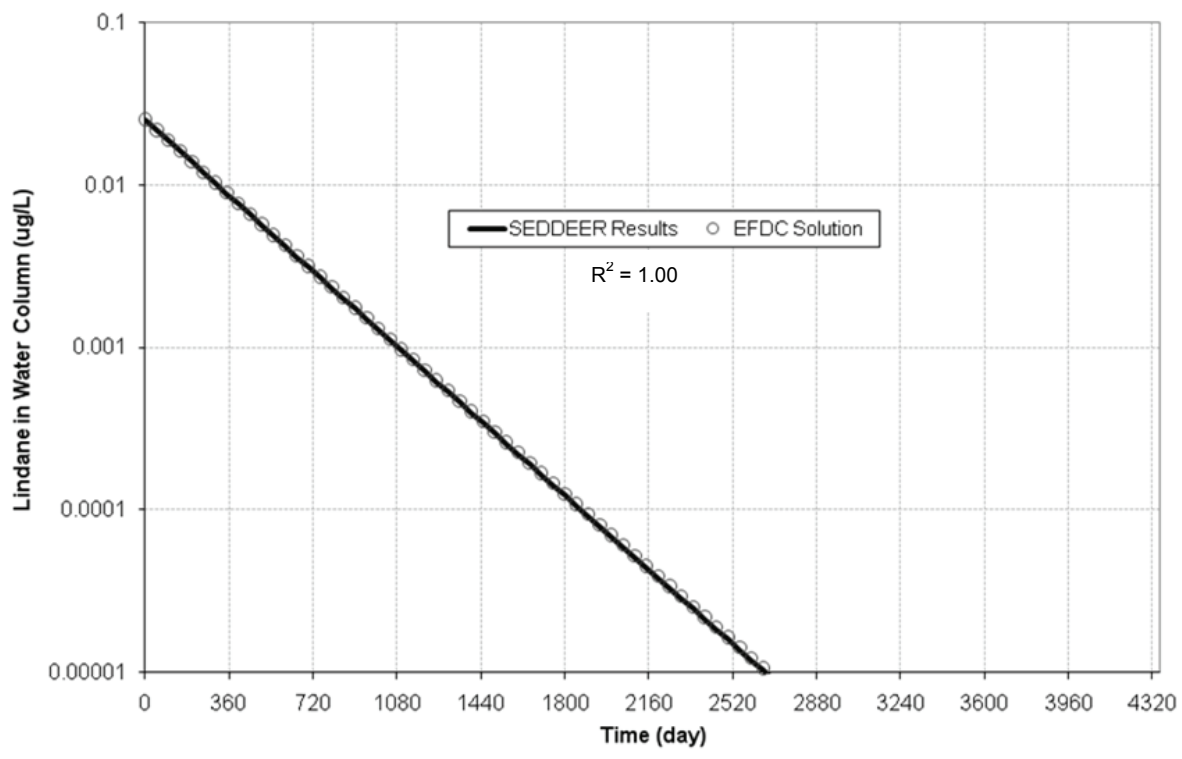

Figure 11. Long-term simulation of lindane in the water column.

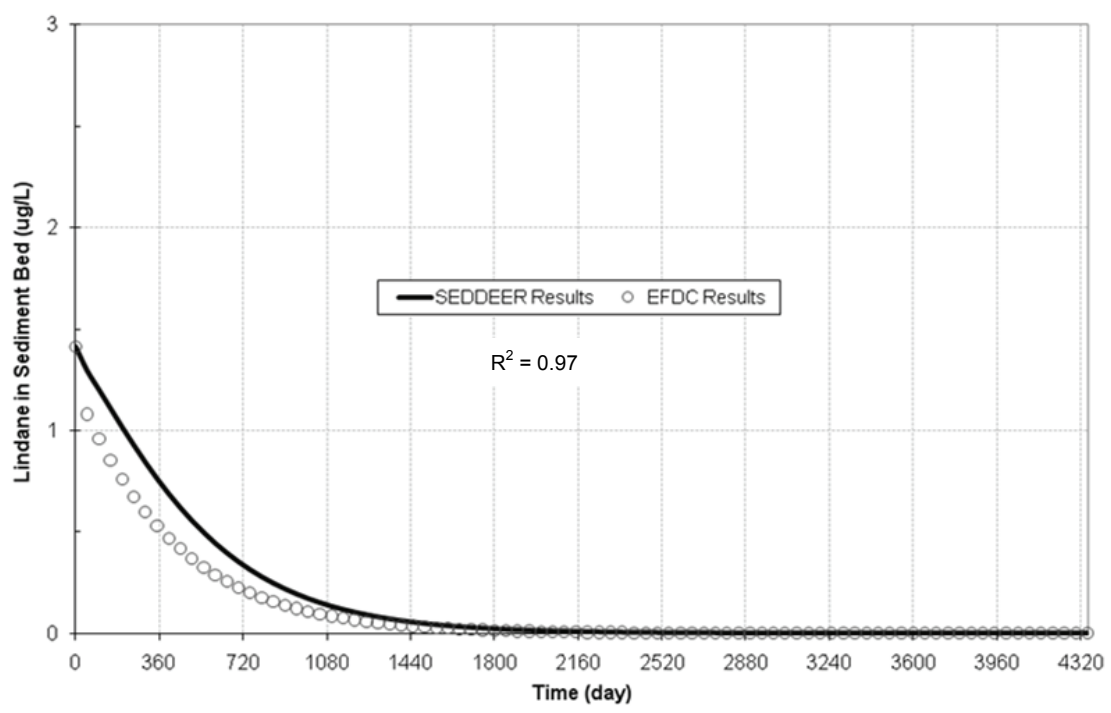

Figure 12. Long-term simulation of lindane in the sediment bed. 


$$
\begin{aligned}
\frac{d(V C)}{d t} & =\sum Q_{i n} C_{i n}-\sum Q_{o u t} C \\
& +\sum \frac{E_{d} A_{j}}{l_{j}}\left(C_{j}-C\right) \pm \text { sources } / \text { sinks }
\end{aligned}
$$

where $V$ is the compartment volume, $C$ is the sediment concentration, $t$ is time, $Q_{i n}$ is the volumetric flow rate of inflow, $C_{i n}$ is the average inflow sediment concentration, $Q_{\text {out }}$ is the volumetric flow rate of outflow, $E_{d}$ is the diffusion coefficient, $A_{j}$ represents the cross-sectional area of the interface, $l_{j}$ is the turbulent mixing length, and $C_{j}$ is the sediment concentration in the adjacent compartment.

WASP solves equation 29 within a 2-D finite difference computational mesh composed of orthogonal quadrilateral cells (Ambrose et al., 1993). SEDDEER (as detailed in the preceding sections) improved the settling velocity model and sink/source terms for sediments by including a flocculation algorithm into the existing WASP sediment formulation. WASP applies SEDDEER to the whole computational domain in a per-cell fashion, linking it to the advection, diffusion, and mass transfer processes (fig. 13).

For a better comprehension of WASP's subroutines and SYSTEM variables (mentioned in the following explanation), the reader is referred to Ambrose et al. (1993) and Wool et al. (2002). SEDDEER was incorporated into the WASP TOXI7 subroutine. SEDDEER adds seven solid types to TOXI7 (one size silt, one size sand, and five classes of flocs) and modifies the sediment settling velocity, sediment bed scheme, and sediment-water interactions by introducing the flocculation algorithms. Additionally, one sediment contaminant was included in the sediment processes, requiring the introduction of an additional state variable. Thus, in the modified WASP TOXI7, SYSTEM 8 is silt, SYSTEM 9 is sand, SYSTEMs 10 through 14 are flocs, and SYSTEM 15 is contaminant. Consequently, significant coding modifications were made within the WASP subroutines, specifically to the main block in the WASP code (WASPB kinetic subroutine), solids subroutine (SOLID), and input/output subroutines. In addition, other common blocks and dependencies were modified or added to fulfill such coupling. Figure 14 shows a schematic of the WASP TOXI7 modification. The incorporation of SEDDEER_FOR into WASP involved modifications of Run_Model.f, SOLID.f, WASP_PARAM.inc, WASPB.f,

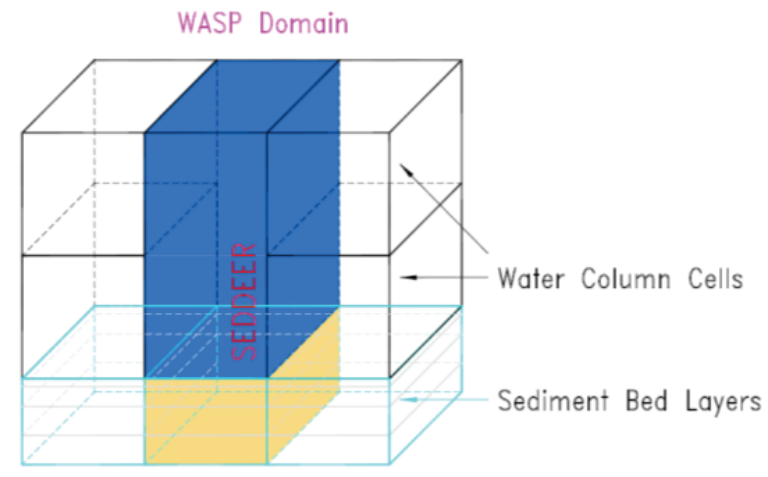

Figure 13. Schematic showing how SEDDEER fits into the Water Quality Simulation Model (WASP).

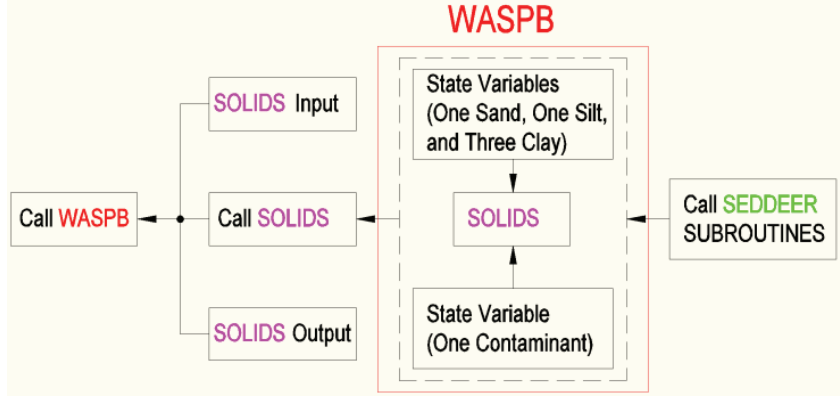

Figure 14. WASP TOX17 subroutine modification to include SEDDEER algorithms into WASP.

WASP1.f, WASP2.f, WASP4.f, and WASP5.f. The addition of SED PARAM.inc, SEDDEER.inc, seddeer_param.inc, SEDDEER_SUBS1.f, SEDDEERint.f, SEDDEERout1.f, and SEDDEERout2.f was also included in the framework.

The newly compiled FORTRAN or VBA SEDDEER versions, along with the FORTRAN source code, are available upon request.

\section{CONCLUSIONS}

The SEDDEER algorithm for flocculation settling was successfully verified for mass conservation of both sediment and contaminant. This article shows the test of SEDDEER performance for estimating settling/deposition without resorting to calibration to fit the experimental data. For shear stresses of 0.00 and $0.05 \mathrm{~Pa}$, the $\mathrm{R}^{2}$ values ranged from 0.98 to 1.00 (corresponding to an NS model fit efficiency range of 0.92 to 0.95 ), showing that the model performed well for low shear stresses. Although for higher shear stress values $(0.50$ and $0.85 \mathrm{~Pa})$ the trend of the deposition rate was well captured by SEDDEER, fitting coefficients $\mathrm{R}^{2}$ and NS indicated that the model did not reproduce the measured values. However, RMSE and PBIAS showed that the simulated and measured values fit adequately. To explain or dissipate this apparent contradiction, additional experimental data are required and will be pursued in the future. Nevertheless, this deposition test case was satisfactory, since the purpose of the validation was to show the capability of SEDDEER to reproduce measured data adequately without using calibration strategies.

The validation of SEDDEER's calculations of DDE transport in the water column showed that SEDDEER reproduced the field measurements very well $\left(R^{2}=0.94\right)$. With regard to DDE in the sediment, the SEDDEER output showed good agreement with the observed data $\left(R^{2}=0.74\right)$. When comparing SEDDEER and EFDC-calculated DDE concentrations in the sediment bed, the model fit efficiency between EFDC and SEDDEER was good, as shown by the coefficient of determination $\left(\mathrm{R}^{2}\right)$ of 0.97 .

For lindane in the water column, the SEDDEER output agreed well with the EFDC-calculated output $\left(\mathrm{R}^{2}=1.00\right)$ and also fit the observed data $\left(\mathrm{R}^{2}=0.85\right)$. With regard to lindane in the sediment bed, there was a consistent $2.00 \mu \mathrm{g}$ $\mathrm{L}^{-1}$ difference between the SEDDEER and EFDCcalculated values. This is explained by SEDDEER and EFDC having different bed layer algorithms for diffusion 
within and between sediment bed layers. Nevertheless, the SEDDEER-calculated output agreed with the field data better than EFDC.

Long-term SEDDEER simulations of DDE and lindane in the water column and the sediment bed were mainly compared to EFDC output due to lack of field data. SEDDEER agreed well with EFDC in the long-term DDE simulation $\left(R^{2}=1.00\right.$ in sediment bed, and $R^{2}=0.997$ in water column) because both models have the same firstorder volatilization and degradation schemes. SEDDEER simulation of DDE in the sediment bed after approximately five years was within the range of the field data. Long-term SEDDEER output for lindane in the water column and sediment bed showed good agreement with EFDC output, with $\mathrm{R}^{2}=1.00$ and $\mathrm{R}^{2}=0.97$, respectively.

Since flocculation of fine-grained sediment may significantly alter the water quality of water bodies, the incorporation of SEDDEER into water quality models that do not include a flocculation algorithm, such as WASP, will improve their calculated output due to SEDDEER's more comprehensive conceptualization and mathematical representation of the sediment processes. Moreover, the improved representation of sediment classes and the bed sediment algorithm that SEDDEER provides will result in more realistic output from water quality models. The integration of SEDDEER into water quality models that model hydrodynamics and contaminant transport makes it applicable to lakes, estuaries, and small and large stream channels.

\section{ACKNOWLEDGEMENTS}

This work was supported by the Kelly Gene Cook Sr. Foundation, the Northern Gulf Institute (NGI), and the NSF-EPSCOR (Grant No. 1010578). The authors thank the editor of this journal and two anonymous reviewers whose comments contributed greatly to the revision of the manuscript.

\section{REFERENCES}

Ambrose, R. B., T. A. Wool, and J. L. Martin. 1993. Part A: Model documentation. In WASP5: The Water Quality Analysis Simulation Program. Athens, Ga.: U.S. EPA Environmental Research Laboratory.

Baugh, J. V., and A. J. Manning. 2007. An assessment of a new settling velocity parameterization for cohesive sediment transport modeling. Continental Shelf Res. 27(13): 1835-1855.

Boyer, J. M., S. C. Chapra, C. E. Ruiz, and M. S. Dortch. 1994. RECOVERY: A mathematical model to predict the temporal response of surface water to contaminated sediments. Tech. Report W-94-4. Vicksburg, Miss.: U.S. Army Engineer Waterways Experiment Station.

Camenen, B. 2007. Simple and general formula for the settling velocity of particles. J. Hydraulic Eng. 133(2): 229-233.

Cerco, C. F., and T. Cole. 1995. User's guide to the CE-QUALICM three-dimensional eutrophication model. Release version 1.0. Tech. Report EL-95-15. Vicksburg, Miss.: U.S. Army Corps of Engineers Water Experiment Station.

Chao, X., Y. Jia, F. D. Shields, S. Y. Wang, and C. M. Cooper. 2007. Numerical modeling of water quality and sediment related processes. Ecol. Modeling 201(3-4): 385-397.

Chapra, S. C. 1997. Surface Water-Quality Modeling. New York,
N.Y.: McGraw-Hill.

Chien, N., and Z. Wan. 1983. Sediment Movement Mechanics. Beijing, China: Science Press (in Chinese).

DePinto, J. V., W. Lick, and J. F. Paul. 1994. Transport and Transformation of Contaminants near the Sediment-Water Interface. Boca Raton, Fla.: CRC Press.

Di Toro, D. M., and P. R. Paquin. 1984. Time-variable model of the fate of DDE and lindane in a quarry. Environ. Toxicol. and Chem. 3(2): 335-353.

Hearn, C. J. 2008. The Dynamics of Coastal Models. Cambridge, U.K.: Cambridge University Press.

Hwang, K.-N., and A. J. Mehta. 1989. Fine sediment erodibility in Lake Okeechobee. Report UFL/COEL-89/019. Gainesville, Fla.: University of Florida, Department of Coastal and Oceanographic Engineering.

Hydroqual, 2004. A Primer for ECOMSED Version 1.4 Users Manual. Mahwah, N.J.: HydroQual, Inc. Available at: http://raritan.dl.stevens-tech.edu/code/shpom/ECOMSED_ Version_4_1_121304.pdf. Accessed September 2012.

Ji, Z.-G. 2008. Hydrodynamics and Water Quality: Modeling Rivers, Lakes, and Estuaries. Hoboken, N.J.: John Wiley and Sons.

Krause, P., D. P. Boyle, and F. Base. 2005. Comparison of different efficiency criteria for hydrological model assessment. Advances in Geosci. 5: 89-97.

Krone, R. B. 1962. Flume studies of the transport of sediment in estuarial shoaling processes. Final Report. Berkeley, Cal.: University of California, Hydrology Engineering Laboratory, and Sanitary Engineering Research Laboratory.

Maa, J. P., J. Kwon, K. Hwang, and H. Ha. 2008. Critical bedshear stress for cohesive sediment deposition under steady flows. J. Hydraulic Eng. 134(12): 1767-1771.

McAnally, W. H. 2000. Aggregation and deposition of estuarial fine sediment. Tech. Report ERDC/CHL TR-00-8. Vicksburg, Miss.: U.S. Army Corps of Engineers Coastal and Hydraulics Laboratory.

McAnally, W. H., and A. J. Mehta. 2001. Significance of aggregation of fine sediment particles in their deposition. Estuarine, Coastal and Shelf Sci. 54(4): 643-653.

Mehta, A. J. 1973. Depositional behavior of cohesive sediments. PhD diss. Gainesville, Fla.: University of Florida.

Migniot, C. 1968. Etude des propriétés physiques de different sédiments très fins et de leur comportement sous des actions hydrodynamiques. La Houille Blanche 7: 591-619.

Moriasi, D. N., J. G. Arnold, M. W. Van Liew, R. L. Bingner, R. D. Harmel, and T. L. Veith. 2007 Model evaluation guidelines for systematic quantification of accuracy in watershed simulations. Trans. ASABE 50(3): 885-900.

Neumeier U., C. Ferrarin, C. L. Amos, G. Umgiesser, and M. Z. Li. 2008. Sedtrans05: An improved sediment-transport model for continental shelves and coastal waters with a new algorithm for cohesive sediments. Computer and Geosci. 34(10): 1223-1242.

Shrestha, P. A., and G. T. Orlob. 1996. Multiphase distribution of cohesive sediments and heavy metals in estuarine systems. $J$. Environ. Eng. 122(8): 730-740.

Teeter, A. M. 2001. Clay-silt sediment modeling using multiple grain classes. Part I: Settling and deposition. Coastal and Estuarine Fine Sediment Processes, 157-172. W. H. McAnally and A. J. Mehta, eds. Amsterdam, The Netherlands: Elsevier Science.

USEPA. 2009. The National Water Quality Inventory: Report to Congress for the 2004 reporting cycle: A profile. Fact sheet. Washington, D.C.: U.S. Environmental Protection Agency. Available at: http://water.epa.gov/lawsregs/guidance/cwa/ 305b/2004report_index.cfm. 
van Rijn, L. C. 1993. Principle of Sediment Transport in Rivers, Estuaries, and Coastal Seas. Amsterdam, The Netherlands: Aqua Publications.

Wang, G., and C. Hu. 2006. Sediment Research Progress. Beijing, China: China Water Power Press (in Chinese).

Whitehouse, R. J. S., R. L. Soulsby, W. Roberts, and H. J. Mitchener. 2000. Dynamics of Estuarine Muds: A Manual for Practical Applications. London, U.K.: Thomas Telford.

Wool, T. A., R. B. Ambrose, J. L. Martin, and E. A. Comer. 2002. Water Quality Analysis Simulation Program (WASP), Version 6.0 Draft: User's Manual. Athens, Ga.: U.S. EPA Watershed and Water Quality Modeling Technical Support Center. Available at: www.epa.gov/athens/wwqtsc/html/wasp.html.

Wu, W., and S. Y. Wang. 2006. Formulas for sediment porosity and settling velocity. J. Hydraulic Eng. 132(8): 858-862.

Xiong, Yi. 2010. Coupling sediment transport and water quality models. PhD diss. Mississippi State, Miss.: Mississippi State University. Available at: http://gradworks.umi.com/ 3432283.pdf. Accessed September 2012.

Xiong, Y., J. L. Martin, and W. H. McAnally. 2010. SEDDEER for VBA (SEDDEER VBA): A sediment transport model for water quality modeling: Users guide and documentation. Draft report. Mississippi State, Miss.: Mississippi State University, Department of Civil and Environmental Engineering. Available at: www2.msstate.edu/ vja1/SEDDEER/seddeer_ user_guide.doc. Accessed September 2012.

Zhu, T. 2006. A depth-averaged two-dimensional water quality model as a research and management tool. PhD diss. Oxford, Miss.: University of Mississippi.

Ziegler, C. K., and B. S. Nisbet. 1995. Long-term simulation of fine-grained sediment transport in large reservoir. J. Hydraulic Eng. 121(11): 773-781. 